\title{
Geneza i funkcjonowanie komisji dobrego porządku*
}

\section{Die Genese und die Funktionierung der Komissionen der guten Ordnung}

1. Niesalysfakcjonujący stan badań - brak syntelycznego ujęcia. 2. Powstawanie pierwszych komisji dobrego porządku - ich samorządowy rodowód. 3. Rozbieżność praktyki w funkcjonowaniu komisji dobrego porządku w latach poprzedzających sejm rozbiorowy i w okresie przed Sejmem Czteroletnim. 4. Brak powszechnego charakteru komisji dobrego porządku. 5. Rozbudowa i funkcjonowanie struktur komisji dobrego porządku na terytorium Rzeczypospolitej. 6. Zakończenie.

1. Unzufriedenstellender Forschungszustand - Mangel an synthetischer Auffasung. 2. Die Entstehung der ersten Komissionen der guten Ordnung - ihre Selbstverwaltungsabstammung. 3. Die Praxisverschiedenheit in der Tätigkeit der Komissionen der guten Ordnung in den Jahren vor dem Teilungssejm und in der Zeit vor Vierjährigem Sejm. 4. Mangel an allgemeinem Charakter der Komissionen der guten Ordnung. 5. Der Ausbau und die Funktionierung der Strukturen der Komissionen der guten Ordnung auf dem Gebiet der Republik. 6. AbschuB.

1. Komisje dobrego porządku - lokalne organy administracji realizujące reformę miejską za panowania Stanisława Augusta - doczekały się wielu opracowań. Większość z piszących zajęła się szczegółowo działalnością komisji w poszczególnych miastach lub regionach ${ }^{1}$. Natomiast w pracach

*Zastosowane skróty: AGAD - Archiwum Glówne Akt Dawnych; APK - Archiwum Państwowe w Krakowie; APP - Archiwum Państwowe w Poznaniu; AUMCS - „Annales Universitatis Mariae Curie-Skłodowska"; B. Czart. - Biblioteka im. Czartoryskich w Krakowie; B. Ossol. - Biblioteka Ossolińskich; BUW - Biblioteka Uniwersytetu Warszawskiego; CPH - „Czasopismo Prawno-Historyczne”; KH - „Kwartalnik Historyczny”; VL - Volumina Legum.

${ }^{1}$ G. Bałtruszajtys, $Z$ badan nad Komisjami Boni Ordinis. Plocka Komisja Boni Ordinis, CPH 1975, t. 27, z. 2; M. Bulitisk i, Monografia miasta Sandomierza, Warszawa 1879, s. 142-146; W. C wik, Komisja Dobrego Porzadku Lubelska jako sqd w sprawach prywainych (1782-1791), СPH 1965, t. 17, z. 1; te nże, Komisje Boni Ordinis dla mniejszych miast województwa lubelskiego (1784-1789), AUMCS 1961 (1962), Sekcja G: Prawo, 1. 8; J. De re si ewic z, Komisja dobrego porzqdku dla wsi wielkopolskiej. Taryfa plac dla czeladzi wiejskiej z 1781 roku, "Studia i Materiały do Dziejów Wielkopolski i Pomorza” 1955, t. 1, z. 1; ten że, Wielkopolskie komisje dobrego porzqdku, CPH 1966, t. 18, z. 2; M. F r a n či ć, Krakowskie komisje boni ordinis (1776-1790), ZNUJ 1961, nr 40, z. 6; S. K ościałk owski, 
ogólnie traktujących o funkcjonowaniu państwa w okresie reform stanisławowskich, komisjom dobrego porządku poświęca się krótkie wzmianki lub wręcz pomija te zagadnienia. Dlatego nie straciły wartości ustalenia I. Baranowskiego i T. Korzona ${ }^{2}$.

W badaniach nad komisjami dobrego porządku dokuczliwy jest brak ujęcia syntetycznego, koniecznego wobec często przeciwstawnych stanowisk różnych autorów i tez formułowanych bez dostatecznej bazy źródłowej. Przedstawiany artykul powstal $w$ trakcie przygotowywania rozprawy habilitacyjnej o działalności administracji w okresie panowania Stanislawa Augusta, w dziedzinie sanitarno-zdrowotnej ${ }^{3}$. W czasie analizy zakresu pracy różnych magistratur poważne trudności wystąpiły przy opracowywaniu genezy i funkcjonowania komisji dobrego porządku. By zweryfikować dotychczasowe ustalenia literatury, podjąć trzeba było własne badania.

2. Geneza komisji dobrego porządku nie została wyjaśniona przez historiografię $w$ sposób satysfakcjonujący.

2.1. Większość autorów za punkt wyjścia do tworzenia tych instytucji bierze sejm z 1764 r., po którym sądy asesorskie (lub król wydając reskrypt) wyznaczyły Komisję Boni Ordinis dla miasta Starej Warszawy ${ }^{4}$. J. Deresiewicz natomiast uważal, że po reformach sejmu konwokacyjnego, sejmiki gospodarskie uznawały, wobec nadmiaru spraw, za konieczne tworzenie osobnego organu, nazwanego komisją dobrego porządku ${ }^{5}$. Jednak część autorów przyjmowala wcześniejszy rodowód komisji. Na przykład J. Lukaszewicz pisal tak o powstałej w Poznaniu w 1756 r. komisji generalnej do rozliczenia

Antoni Tyzenhauz podskarbi nadworny litewski, t. 1, Londyn 1970, s. 461-463; W. R u s ińs ki, $Z$ dziejów Kalisza w okresie Oświecenia. Budżet miasta ustanowiony w r. 1788 przez Komisje Dobrego Porzqdku, „Rocznik Kaliski" 1968, t. 1; te nże, Życie codzienne w Kaliszu w dobie Oświecenia, Poznań 1988; W. S moleń sk i, Komisya Boni Ordinis Warszawska (1765-1789), Warszawa 1913; J. S obcza k, Dzialalność Komisji Dobrego Porzadku we Wschowie, „Rocznik Leszczyński", [Poznań] 1985, t. 7; t e n że, Ludność żydowska Wschowy w poczq̨tkach 2 polowy XVIII w. (w świetle ustalén Komisji Dobrego Porzqdku), [w:] Żydzi w dawnej Rzeczypospolitej, Ossolineum 1991, s. 120-128; B. Ty s zk i ewi c z, Dzialalność Poznańskiej Komisji Dobrego Porzqdku (1779-1784), Poznań 1965.

${ }^{2}$ I. B a ranowski, Komisje porzqdkowe (1765-1788), Kraków 1907; T. K orzon, Wewnętrzne dzieje Polski za Stanislawa Augusta (1764-1794), Kraków-Warszawat 1897, t. 2, s. $296-297$; t. 4 , s. 315 .

${ }^{3}$ T. S r ogos z, Problemy sanitarno-zdrowotne $w$ dzialalności administracji Rzeczypospolite; w okresie stanislawowskim, Łódź 1993.

${ }^{4}$ I. Baranowski, op. cit., s. 5-6; M. Bogucka, H. Samsonowicz, Dzieje must $i$ mieszczaństwa w Polsce przedrozbiorowej, Ossolineum 1986, s. 576 577; M. F r a n č ič, op. cit., s. 81-82; W. Smoleński, op. cit., s. 7; t enże, Mieszczaństwo warszawskie w końcu wieku XVIII, Warszawa 1976, s. 99; J. S obczak, Dzialalność..., s. 114; tenże, Ludność żydowska..., s. 120 .

${ }^{5}$ J. Deresiewicz, Komisja dobrego porzqdku..., s. 287. 
czopowego $^{6}$, co nie odpowiadalo $w$ pelni ani kompetencjom tego organu zarządu lokalnego, ani jego obszarowi dzialania. Ł. Charewiczowa przypuszczała, że już Królewska Komisja we Lwowie otrzymała zadania porządkowe (gdy Komisja warszawska organizacyjne) w kontynuacji działań specjalnej komisji, funkcjonującej w latach 1756-1757, pod przewodnictwem starosty nowogrodzkiego - Szczęsnego Czackiego?. J. Staszewski wskazał na powstanie pod koniec panowania Augusta III nowych ciał zarządzających miastami wielkopolskimi, co stworzylo fundament pod komisje dobrego porządku, podejmujące odbudowę miast za Stanisława Augusta ${ }^{8}$. Zauważmy, że w historiografii nie poszukiwano obcych wzorców. Jedynie A. Zahorski odwołal się do narzuconych miastom włoskim komisji dobrego porządku, stwierdzając jednak, że problematyka ta wymaga dalszych badań".

2.2. Teze o samorządowym rodowodzie komisji dobrego porządku potwierdzają dzieje sejmikowe i - choć szczuple - źródła. Na przełomie 17. i 18. w. powoływano rady wojewódzkie, które były rodzajem stałych komisji sejmikowych o szerokim, ale nie $w$ pelni określonym zakresie kompetencji ${ }^{10}$. Scjm z 1717 r. położył wprawdzie kres radom wojewódzkim, ale nie administracyjnym funkcjom sejmików, które po prostu musiały podjąć czynności zarządzające $\mathrm{z}$ powodu braku innych organów wykonawczych. W województwie krakowskim na sejmikach gospodarskich powoływano - na wzór byłych rad wojewódzkich - komisje zajmujące się rozdziałem pieniędzy zgodnie z laudami ${ }^{11}$. W wyniku ograniczenia władzy sejmików w latach $1764-1768$ powstała luka w zarządzie lokalnym ${ }^{12}$. Uważam, że ten właśnie fakt stanowił główną przyczynę powołania komisji dobrego porządku przez króla i Asesorię, choć nie bez znaczenia była też troska władz naczelnych o stan miast i realizację reform.

${ }^{6} \mathrm{~J}$. Luk aszewicz, Obraz historyczno-statystyczny miasta Poznania $w$ dawniejszych czasach, t. 1, Poznań 1838, s. 388.

7. Charewiczowa, Lwów w odnowie 1766-1769, [w:] Studia lwowskie, Lwów 1932, s. 116.

8 J. Stas zewski, August III Sas, Ossolineum 1989, s. 284.

${ }^{9}$ A. Zahorski, Centralne instytucje policyjne $w$ Polsce $w$ dobie rozbiorów, Warszawa 1959 , s. 25.

10 W. K riegse is e n, Samorzqd szlachecki w Malopolsce w latach 1669-1717, Warszawa 1989, s. 56-67; te nże, Sejmiki Rzeczypospolitej szlacheckiej w XVII i XVIII wieku, Warszawa 1991, s. 243-244; A. Lity ński, Szlachecki samorzqd gospodarczy w Malopolsce (1606-1717), Katowice 1974 , s. $80-81$.

${ }^{11} \mathrm{~K}$. P r zy boś, Sejmik województwa krakowskiego w czasach saskich (1697-1763), Kraków 1981 , s. 122.

${ }^{12}$ A. Pawiński, Rzqdy sejmikowe w Polsce 1572-1795 na tle stosunków województw kujawskich, Warszawa 1978, s. 514-516. Według skrajnego stanowiska A. Lityńskiego, między okresem saskim a powołaniem komisji porządkowych cywilno-wojskowych nie istniały instytucje samorządu szlacheckiego (Samorząd szlachecki w Polsce XVII-XVIII wieku, KH 1992, R. 99, nr 4 , s. 30). 
2.3. Idea tworzenia lokalnych organów wykonawczych najpełniejszy wyraz znalazła na terenie Wielkopolski. Z zachowanego Zbioru papierów tyczqcych czynności Komisji Boni Ordinis ustanowionych w województwie poznańskim $i$ kaliskim ab anno 1756 ad 1767 można dowiedzieć się o powołaniu przez sejmik gospodarski ciała kolegialnego, składającego się ze szlachty ${ }^{13}$. Komisji przewodniczyli wojewodowie kaliscy: najpierw Augustyn Działyński, a po jego śmierci - Ignacy Twardowski. Komisja Boni Ordinis, działająca w trakcie obrad sejmikowych, zajmowała się głównie sprawami skarbowymi i miejskimi. W swojej działalności powoływała się na konstytucje sejmowe i lauda sejmikowe. Na przykład w 1766 r., wydając deklaracje o zbiegach, komisarze wyraźnie zaznaczyli, że wypełniają wolę sejmujących stanów oraz ostatniego laudum sejmiku województwa poznańskiego i kaliskiego ${ }^{14}$. Wobec jednoczesnego powołania podobnego organu we Lwowie można wysunąć hipotezę o istnieniu pod koniec epoki saskiej ogólniejszej myśli tworzenia zarządu lokalnego. Sprawy te wymagają dalszych badań, zwlaszcza z uwzglęnieniem nie znanego dotąd rękopisu z Biblioteki im. Czartoryskich w Krakowie, który zawiera ciekawe informacje $\mathrm{z}$ terenu Wielkopolski, głównie $\mathrm{z}$ dziedziny spoleczno-gospodarczej.

2.4. Uważam, że powołując komisje dobrego porządku w pierwszych latach panowania Stanisława Augusta, wykorzystano tradycje samorządu szlacheckiego. Tym razem inicjatywę przejęły władze centralne, wyznaczając komisarzy i ograniczając ich kompetencje do spraw miejskich. Utrzymano natomiast szlachecki skład tych organów oraz nazwę kojarzącą się $\mathrm{z}$ sejmikami boni ordinis $\mathrm{i}$ ich ciałami wykonawczymi. Komisje miały wdrażać w życie, zapoczątkowaną w 1764 r. zniesieniem jurydyk, reformę miejską.

3. W działalności komisji dobrego porządku zauważyć można dwa okresy. Pierwszy - trwający od 1765 r. do sejmu rozbiorowego, i drugi - od $1776 \mathrm{r}$. aż do reform Sejmu Czteroletniego. Okresy te charakteryzują się różnymi warunkami politycznymi, w tym również odmiennością struktur administracyjnych.

3.1. Pierwszy okres funkcjonowania komisji dobrego porządku zaznaczył się dynamiczną akcją na rzecz modernizacji państwa. W $1764 \mathrm{r}$. sejm konwokacyjny powołal osobne dla Korony i Litwy komisje wielkie: skarbu i wojska, co uważa się za początek nowożytnej administracji w Rzeczypospolitej. Stanisław August zorganizował w $1765 \mathrm{r}$. Gabinet i za jego posrednictwem starał się kierować sprawami państwowymi, co zrodziło konflikt

\footnotetext{
13 B.Czart., nr 784.

14 Ibidem, s. $120-121$.
} 
$z$ ugrupowaniem Czartoryskich ${ }^{15}$. Emancypacyjne zabiegi króla i dążenie do reform spowodowaly też przeciwdziałanie Katarzyny II, co w konsekwencji doprowadziło do konfederacji barskiej i rozbioru. Przełom polityczny stworzył warunki do formulowania różnych projektów modernizowania państwa. Jednak elity polityczne dzialaly ostrożnie, nie zawsze mając pewność co do pozytywnych efektów swoich decyzji.

4. W literaturze istnieją rozbieżności co do liczby komisji dobrego porządku ustanowionych do 1775 r. reskryptami królewskimi. Większość autorów jest zdania, że w 1765 r. utworzono dwie, tj. Komisje Boni Ordinis w Warszawie i Królewską Komisję Brukową we Lwowie. J. Praśnik wręcz pisał o zapoczątkowaniu komisji w tych dwóch ośrodkach niejako na próbę, dla sprawdzenia skuteczności ich działania ${ }^{16}$. W. Trzebiński bez uzasadnienia źródłowego dodal dwie dalsze, tj. dla Wieliczki i Kamieńca Podolskiego, co bezkrytycznie powtórzono $w$ syntezie dziejów miast i mieszczaństwa M. Boguckiej i H. Samsonowicza ${ }^{17}$. Tę propozycję należy odrzucić zdecydowanie. Co więcej - można zastanowić się nad istnienier jedynie Komisji Boni Ordinis w Warszawie. Przemawia za tym początkowa ostrożność elit w reformowaniu państwa i praktyka stosowania rozwiązań próbnych. Ostrożność ta spowodowana była również brakiem podobnych instytucji $w$ innych krajach Europy - przy tworzeniu komisji dobrego porządku nie powolywano sie przynajmniej na obce wzorce ${ }^{18}$. Znawca dziejów Kamieńca Podolskiego - A. J. Rolle - podał, że w tym mieście Komisja Boni Ordinis zebrała się na pierwszym posiedzeniu dopiero w $1785 \mathrm{r}^{19}$

4.1. Przewodniczącym warszawskiej Komisji Dobrego Porządku został wojewoda rawski - Bazyli Walicki. W $1766 \mathrm{r}$. zaczęto pracę nad rozpoznaniem przywilejów, dóbr i dochodów miejskich ${ }^{20}$. Komisja zreorganizowała w $1770 \mathrm{r}$. Urząd Ekonomiczny. W 1767 r. przeprowadzono z jej polecenia rewizję

${ }^{15}$ M. R y m s y n a, Gabinet Stanislawa Augusta, Warszawa 1962, s. 35-37.

${ }^{16}$ L. Charewiczowa, op. cit., s. 115; W. Cwik, Komisje Boni Ordinis..., s. 289-290; N. Frančič, op. cit., s. 83; J. Pt a śnik, Miasta i mieszczaństwo w dawnej Polsce, Warszawa 1949 , s. 323.

${ }_{17}$ M. Bogucka, H. Samsonowicz, op. cit., s. 577; W. Trzebiński, Nadzór budowlany $i$ przepisy policyjno-budowlane $w$ Polsce Oświecenia jako środki naprawy miast królewskich, [w:] Miasta doby feudalnej w Europie środkowo-wschodniej, Warszawa-Poznań-Toruń 1976 , s. 256.

${ }^{18} \mathrm{~W}$ okresie Sejmu Czteroletniego żadna dyskusja polityczna nie mogla sį̨ obejšć bez powoływania się na takie wzory (A. Grześkowiak-Krawicz, Obce wzory ustrojowe $w$ dyskusjach publicystycznych Sejmu Czteroletniego, [w:] Sejm Czteroletni i jego tradycje, Warszawa 1991, s. 89-91). Tę tendencje obserwować można i w czasach saskich, co należy wiązać z tzw. „europeizacją" Rzeczypospolitej.

19 A. J. Rolle, Kamieniec Podolski w XVIII stuleciu, „Przegląd Lwowski” 1873, t. 6, s. 813.

${ }^{20}$ W. Smoleński, Komisya..., s. 9-17. 
konfraterni. Rezultatem tych działań było $\mathrm{m}$. in. uporządkowanie organizacji kontuberni cyrulickiej miasta Pragi. Od 1768 r. aż do 1822 r. prowadzone były porządne protokoly corocznych wyborów starszego i podstarszego, sesji $\mathrm{i}$ innych spraw zgromadzenia. Na pierwszym posiedzeniu 26 września 1768 r. prezydent Pragi - Ignacy Szperliński, do ksiegi protokołów wpisal następującą adnotację: ...którzy to starsi, aby porzqdek należyty $w$ rzqqdzeniu osób do contubernium należacych $i$ zachowanie obrzadków prawa ściśle utrzymywali zalecam ${ }^{21}$. Reorganizacja zgromadzenia praskich cyrulików świadczy o wykraczaniu działalności Komisji poza granice Starej Warszawy. Prócz czynności rozpoznawczo-organizacyjnych Komisja warszawska w pierwszych latach istnienia osiągnęła niewiele. Na przykład w zakresie higieny miejskiej komisarze zajęli się jedynie sprawą wymurowania kanałów na terenie Nowej Warszawy i zalecili reperację $\operatorname{rur}^{22}$. Wynikało to $\mathrm{z}$ wykazu kompetencji i harmonogramu czynności zakreślonych przez reskrypt królewski, przyjętego jako wzorzec przy powoływaniu komisji dobrego porządku w okresie istnienia Rady Nieustającej.

4.2. Na czele Królewskiej Komisji Brukowej we Lwowie stanął wojewoda bełzki - Ignacy Cetner. Mimo kilku zmian w składzie, nie pracowała ona rytmicznie, a absencja komisarzy była znaczna ${ }^{23}$. W reskryptach królewskich ustalono zakres kompetencji podobny do obowiązków istniejącej od $1743 \mathrm{r}$. Komisji Brukowej w Warszawie. Stąd pojawia się dla badaczy problem, czy powolany dla Lwowa organ zarządu lokalnego można zaliczyć do realizujących idę komisji dobrego porządku. Mimo braku niektórych uprawnień $Ł$. Charewiczowa stwierdziła, że lwowska Komisja Brukowa już stanowila surogat komisji porządkowych ${ }^{24}$. Zwrócić można uwage, że Komisji lwowskiej nie wyposażono $w$ najistotniejsze kompetencje, np. w zakresie organizacji władz miejskich. Dopóki jednak nie uzyskamy nowych informacji źródłowych, przyjąć należy z powyższym zastrzeżeniem stanowisko L. Charewiczowej.

4.3. Problemem komisji dobrego porządku zająl się sejm delegacyjny $z$ lat 1767-1768. Niektórzy autorzy, za I. Baranowskim uznali, że postanowiono wówczas wysłać do wszystkich miast królewskich komisje, które miały zrealizować reformę miejską w myśl nowych sejmowych konstytucji ${ }^{25}$. J. Sobczak stwierdził ostrożniej, że jedynie zadeklarowano powołanie komisji

21 BUW, nr 123, k. 2.

${ }_{22}$ F. Giedroyc, Wodociagi $i$ kanaly miejskie. $Z$ dziejów hygieny $w$ dawnej Polsce. Warszawa 1910, s. 7, 71.

${ }^{23}$ Ł. Charewiczowa, op. cit., s. 120-131.

24 Ibidem, s. 134.

25 I. Bar a nowski, op. cit., s. 6; W. Ćwik, Komisje Boni Ordinis..., s. 289; M. F r a n čič, op. cit., s. 82; J. Ptáśn $\mathrm{k}$, op. cit. 
dobrego porządku, określając ich cel i zakres działania ${ }^{26}$. W rzeczywistości w konstytucji Warunek miast i miasteczek naszych królewskich w Koronie $i W$. Ks. Lit. nie było mowy o obligatoryjnym tworzeniu komisji i ich terytorium działania, wyliczono natomiast ogólnie kompetencje: sprawy przywilejów i finansów miejskich, propinacji, ludności żydowskiej i szpitali27. Powołanie konkretnych komisji i określenie szczegółowego zakresu obowiązków miało być realizowane przez reskrypty królewskie.

4.3.1. W pierwszym okresie funkcjonowania komisji wprowadzono je na próbę w Warszawie, gdzie działała już porządkująca wcześniej miasto Komisja Brukowa, oraz we Lwowie (z ograniczonymi kompetencjami). Zapoczątkowanie reformy od największych ośrodków stanowiło zasadę pracy administracji centralnej w okresie panowania Stañisława Augusta. W 1768 r. sejm, uznając zasadność istnienia organów zarządzających miastami królewskimi, stworzył delegacje prawną do powoływania komisji dobrego porządku w całej Rzeczypospolitej. W dalszym ciągu jednak elity polityczne wykazywały ostrożność, dając królowi swobodę wyznaczania komisji $\mathrm{i}$ wyposażenia ich $\mathrm{w}$ odpowiednie kompetencje. Najwidoczniej uznano, że jednostkowe decyzje lepiej wnikną w lokalne problemy niż dałoby się to osiągnąc $w$ sztywnych ramach konstytucji sejmowej. Jednak z powodu skomplikowanej sytuacji politycznej, realizację woli sejmujących stanów trzeba było odłożyć na kilka lat.

4.3.2. Po sejmie rozbiorowym nastąpila stabilizacja polityczna, która sprzyjała pracy na rzecz modernizacji Rzeczypospolitej. Najważniejszą role odgrywali wówczas ambasador rosyjski - Otto Magnus Stackelberg i Stanisław August, co nazwano rządami ambasadorsko-królewskimi. Naczelnym organem wykonawczym była w tym czasie Rada Nieustająca, która solidnie spełniała swoje obowiązki. Z biegiem czasu król doprowadził w jej lonie do przeobrażeń organizacyjnych i kadrowych. Także opozycja, która w początkowej fazie wzgardziła stanowiskami w Radzie, przyłączyła się później do działań konstruktywnych. W. Konopczyński ocenil, że w okresie Rady Nieustającej postępowała cicha i „organiczna" praca ${ }^{28}$. Efekty tej polityki stały się również widoczne $w$ ośrodkach prowincjonalnych, gdzie funkcjonowały komisje dobrego porządku.

5. Zasady działania komisji dobrego porządku w okresie Rady Nieustającej należą do najmniej zbadanych tematów. Nieporozumienia dotyczą wielu kwestii, łącznie $z$ datą wznowienia ich działalności. T. Korzon podał, że

\footnotetext{
26 J. S o bczak, Dzialalność..., s. 114.

27 VL, t. 7, wyd. J. Ohryzko, Petersburg 1860, s. 351-353.

28 W. Konopczyńs ki, Dzieje Polski nowożytnej, t. 2, Warszawa 1986, s. 220.
} 
od 1777 r. wyznaczano komisje dla różnych miast pod prezydencją wojewody lub starosty, co powtórzył F. Koneczny ${ }^{29}$. Prawdopodobnie T. Korzon pomylił fakt powoływania komisji dobrego porządku z początkiem licytowania propinacji w miastach. Podstawowym błędem większości prac jest też uznawanie tezy o funkcjonowaniu komisji dla poszczególnych miast, w czym utwierdził opinię historyczną artykuł W. Ćwika ${ }^{30}$. Jedynie J. Deresiewicz sprzeciwił się zdecydowanie tej tezie, choć nie przedstawił dowodów źródłowych dla potwierdzenia szerszego zasięgu terytorialnego pracy komisji ${ }^{31}$. Natomiast nieporozumieniem jest twierdzenie W. Trzebińskiego, że w 1776 r. Rada Nieustająca przedstawiła sejmowi projekt utworzenia wojewódzkich organów Departamentu Policji, pod nazwą komisji boni ordinis, których nie należy mylić - jak pisze - z komisjami o tej samej nazwie, powolywanymi dla miast ${ }^{32}$. W rzeczywistości w 1776 r. debatowano nad inną kwestią, natomiast w Uwagach do polepszenia rządu polskiego, znajdujących się w aktach sejmu z 1786 r., postulowano powołanie rad wojewódzkich (zwanych też nacjonalnymi), składających się z 5-6 osób ${ }^{33}$. Jako uzasadnienie wskazywano trudności decydowania przez Radę Nieustającą o lokalnych problemach oraz troską o porządek i wygodę mieszkańców. Trudno dociec, czy miała to być ulepszona wersja komisji dobrego porządku, czy też nowa struktura administracji. Projekt upadl, a Rada Nieustająca zdecydowala się na tworzenie wydziałów policyjnych dla miast królewskich na czele $\mathrm{z}$ komisarzami ${ }^{34}$.

5.1. W literaturze przedmiotu dotkliwie brakuje rozważań na temat realizacji ogólnych przepisów, normujących zasady wydawania przez króla reskryptów na komisje dobrego porządku. Na sejmie w $1776 \mathrm{r}$. rozpatrywano projekt o odnowieniu (reasumpcji) konstytucji z 1768 r. Warunek miast i miasteczek naszych królewskich $w$ Koronie $i W$. Ks. Lit. ${ }^{35}$ Jednak sprawa nie znalazła finału w postaci decyzji sejmujących stanów. Ze wzoru reskryptu królewskiego z 12 sierpnia 1778 r. wynika jasno, że komisje dobrego porządku ustanawiano dla całych województw ${ }^{36}$. Najpierw, działając na sesjach, miały porządkować sprawy stolicy województwa, później zaś - kontynuować działalność w innych miastach królewskich swojego terenu. Wzór reskryptu zawierał również

${ }^{29}$ T. Korzon, op. cit., t. 2, s. 296; F. K oneczny, Dzieje administracji $w$ Polsce $w$ zarysie, Wilno 1924, s. 219.

30 W. Cw ik, Komisje Boni Ordinis..., s. 290.

31 J. Deresiewicz, Wielkopolskie komisje..., s. 162. Również G. Bałtruszajtys podała, że płocka Komisja Dobrego Porządku została wyznaczona dla miast królewskich większych i pomniejszych (op. cit., s. 222).

32 W. Trzebiński, op. cit., s. 259.

33 AGAD, Zbiór Popielów, nr 132, k. 264-264 v.

34 A. Zahorski, op. cit., s. 35-40.

35 AGAD, Zbiór Popielów, nr 113, k. 39.

36 AGAD, tzw. Metryka Litewska, dz. IX, nr 17, k. 213-216. 
zakres obowiązków komisji. Na tej podstawie wydawano decyzje wyznaczające je dla poszczególnych województw lub ziem.

5.2 Autorzy przedstawiający ujęcie syntetyczne nie zdołali ustalić liczby komisji dobrego porządku. Wynika to zarówno $\mathrm{z}$ niewiedzy historyków o zasięgu terytorialnym komisji, jak również z trybu ich wyznaczania. T. Korzon podal, że z całą pewnością dzialały komisje w Krakowie, Warszawie, Poznaniu, Piotrkowie, Kaliszu, Wschowie, Lublinie, Sandomierzu, a ponadto zostaly wyznaczone dla Brześcia Litewskiego, Grodna, Kazimierza Dolnego, Żytomierza, Wielunia, Brześcia Kujawskiego oraz ziem: różańskiej, dobrzyńskiej i bielskiej. Dla Kamieńca Podolskiego, Lomży, Mińska Litewskiego oraz województw: wołyńskiego i kijowskiego król został proszony o mianowanie komisji ${ }^{37}$. I. Baranowski odnotował pracę łęczyckiej Komisji Dobrego Porządku, a G. Bałtruszajtys opisała działalność Komisji płockiej ${ }^{38}$. Wykaz ten można zweryfikować, czego przykładem jest Wschowa. J. Deresiewicz i G. J. Rolbiecki uznali, że dla tego miasta powołano osobną Komisję Dobrego Porządku, czemu sprzeciwił się J. Sobczak, twierdząc, że w rzeczywistości pracowała tam Komisja poznańska ${ }^{39}$. Skoro obowiązywala zasada wyznaczania komisji dla województw lub ziem, to zasadne może być tylko ostatnie stanowisko. Drugim przykładem może być Komisja wieluńska, powolana nie dla jednego ośrodka, ale dla wszystkich miast królewskich ziemi wieluńskiej ${ }^{40}$. Nieporozumienia dotyczące Wschowy lub mniejszych miast województwa lubelskiego wyniknęly wskutek nierytmicznej pracy komisji, zmian ich składu osobowego lub wydzielania mniejszych zespołów komisarzy (najczęściej mieszkających w pobliżu).

5.3. Trudno jest ustalić, czy król wydał reskrypty dla wszystkich jednostek terytorialnych. Dotyczy to szczególnie wschodnich obszarów Rzeczypospolitej, $\mathrm{i}$ to nie ze względu na trudności z przekazami źródłowymi, lecz z powodu szczególnej polityki wladz naczelnych. Najpierw bowiem starano się wyznaczyć komisje dla Wielkopolski, Mazowsza i Małopolski Zachodniej; później zaś dla województw i ziem poza linią Bugu, gdzie zaczęto akcję dopiero w połowie lat osiemdziesiątych 18 . w. Na przykład wspomniana wcześniej podolska Komisja Dobrego Porządku zaczęla pracę w 1785 r. Na Podolu

37 T. Korzon, op. cit., t. 2, s. 296-297.

${ }^{38}$ I. Baranowski, op. cit., s. 8; G. Bałtruszajtys, op. cit., s. 221--227. W. Trzebiński szacuje, że na ogólną liczbę 214 miast królewskich w Koronie efektywną działalnościaz komisji objętych zostało zaledwie około 30 (op. cit., s. 261-262). Podobne obliczenia należy traktować bardzo ostrożnie, gdyż nie odnoszą się do rzeczywistego zasięgu terytorialnego pracy komisji oraz nie wynikają $\mathrm{z}$ wyczerpującej kwerendy źródłowej we wszystkich dostępnych aktach miejskich.

39 J. Deresi ewicz, Wielkopolskie komisje..., s. 170; G. J. R olbi ecki, Prawo przemyslowe miasta Wschowy w XVIII w., Poznań 1951, s. 40; J. Sobczak, Dzialalność..., s. 115-116.

40 AGAD, tzw. Metryka Litewska, dz. VII, nr 48, k. 91-94 v; APP, Akta miasta Grabów, $\mathrm{nr} \mathrm{I} / 17, \mathrm{I} / 18$. 
i Ukrainie komisje działały nieco lepiej niż w Wielkim Księstwie Litewskim, bo zauważamy nawet ślad ich współdziałania w obliczu klęsk elementarnych. Komisja kijowska, na skutek doniesień o szerzeniu się dżumy w okolicy Jass, zwróciła się 14 maja 1789 r. do komisji wołyńskiej, podolskiej i braclawskiej, aby przedsięwzięły środki ostrożności, które mogłyby chronić również województwo kijowskie ${ }^{41}$. $\mathrm{Z}$ informacji tej dowiadujemy się o istnieniu Komisji Dobrego Porządku województwa bracławskiego. W Prawidlach dla magistratu Kowna od Komisji Boni Ordinis z 8 marca 1788 r. zajeto się zaledwie sprawami wstępnymi, tj. dokumentami (archiwum), funduszami i niektórymi jednostkami gospodarczymi ${ }^{42}$. Sytuacja ta wskazuje na późne wydanie reskryptu królewskiego.

Być może różnice $w$ polityce względem poszczególnych obszarów Rzeczypospolitej wynikały $z$ liczby miast $\mathrm{i}$ ich znaczenia gospodarczego. $\mathrm{Na}$ tym etapie badań można stawiać zaledwie hipotezy, które dopiero po konfrontacji $\mathrm{z}$ rozproszonymi źródłami, glównie $\mathrm{w}$ aktach miejskich, będzie można zweryfikować. Podobne zresztą trudności, wynikające $\mathrm{z}$ różnych dat wydawania reskryptów, ich ponawiania, charakteru pracy komisji itp., pojawiają się w każdym przypadku podejmowania studiów nad działalnością konkretnej komisji dobrego porządku.

5.4. W skład komisji wchodzili przedstawiciele okolicznej szlachty, przewodniczyli zaś senatorowie (wojewoda, kasztelan itp.). Natomiast uczestnictwo starosty musiało być dla komisji uciążliwe, skoro jego działalność podlegała kontroli. Liczba komisarzy ustalana reskryptem, zależala od królewskiej decyzji. Na sekretarza wyznaczano jednego z urzędników magistratu. Uchwały zapadały większością głosów. Ze względów pragmatycznych (slabej frekwencji komisarzy) ustalano niskie, najczęściej trzyosobowe qourum ${ }^{43}$. Reskrypty królewskie dokładnie określały zadania: prawodawcze (opracowanie ordynacji dla miast), sądownicze i kontrolne. Decyzje kierowano do wykonania magistratom lub konkretnym urzędnikom miejskim czy instytucjom. Po uporządkowaniu niezbędnych spraw $w$ stolicy województwa lub ziemi ( $\mathrm{z}$ reguły trwało to kilka miesięcy) przenoszono urzędowanie do kolejnych miast królewskich, by następnie wrócić w celu kontroli wykonania uchwał i wprowadzenia dalszych reorganizacji, do centrum jednostki terytorialnej.

Jakość pracy komisji zależała $w$ dużym stopniu od przewodniczącego Do najbardziej znanych należą Kazimierz Raczyński (poznańskiej) i Kajetan Hryniewiecki (lubelskiej) ${ }^{44}$. W literaturze panuje pogląd, że bardzo slabo

41 B.Czart., nr 953, s. 41.

42 B.Czart., nr 857 , s. $263-273$.

43 I. Baranowski, op. cit., s. 14; B. Tyszkiewicz, op. cit., s. 14.

$44 \mathrm{O}$ Hryniewickim taką opinię wydał $\mathrm{K}$. K oźm ia n: ...mqż prawy, nieskażony $i$ czynny, wielka usilnościq, wytrwalościq $i$ pracq wydobyl to opuszczone $i$ nieszczésliwe miasto $z$ rozwalin, $z$ popiolów i blota (Pamiętniki, t. 1, Ossolineum 1972, s. 83). 
działała Komisja krakowska aż do momentu powolania w $1786 \mathrm{r}$. nowego składu, na czele $\mathrm{z}$ wojewodą krakowskim - Piotrem Małachowskim ${ }^{45}$. Tezę tẹ można przyjąć $z$ pewnymi zastrzeżeniami. Mianowicie podobne zjawiska zachodziły $\mathrm{i} w$ innych jednostkach terytorialnych, gdzie komisarze $\mathrm{z}$ różnych powodów nie byli zainteresowani uczestnictwem w posiedzeniach. Stąd brało się ponawianie reskryptów królewskich, mobilizowanie do pracy, zmiana składów. Ponadto jednak krakowska Komisja Dobrego Porządku za prezesury wojewody pomorskiego - Ignacego Franciszka Przebendowskiego, opracowała ordynację dla miasta w $1778 \mathrm{r} .{ }^{46}$, co należało do najważniejszych wstępnych zadań. Faktem jest, że Komisja wyszła poza stolicę swojego województwa dopiero w latach 1787-1788; z tego okresu zachowały się akta jej działalności dla miasta Kazimierz ${ }^{47}$. W 1787 r., na zlecenie krakowskiej Komisji Dobrego Porządku, opracowano Zbiór projektów ściagajacych sie do wprowadzenia $w$ Polszcze po miastach dobrego rzadu, w którym do poprzedniej ordynacji dodano nowe szczegóły ${ }^{48}$. Dzieło to powstało w związku $\mathrm{z}$ wizytą króla w Krakowie, do niego bowiem było adresowane.

6. W działalności komisji dobrego porządku odzwierciedlał się schemat narzucony przez konstytucje sejmowe i decyzje władz naczelnych oraz prawie jednobrzmiące reskrypty królewskie. Ponadto jako wzór do naśladowania wskazywano działalność niektórych komisji. Szczególną rolę odegrał przykład Komisji Dobrego Porządku województwa poznańskiego, której ordynację Rada Nieustająca nakazała ogłosić drukiem ${ }^{49}$. Dobrze charakteryzuje stosunki komisji $\mathrm{z}$ władzami naczelnymi zagadnienie rozpoznania funduszy szpitalnych. Sejm z 1780 r. przekazal sprawy szpitalnictwa do kompetencji komisji dobrego porządku, a kontrolę nad nimi mial sprawować Departament Policji Rady Nieustającej ${ }^{50}$. Departament ten chcąc wywiązać się z obowiązku nadzoru nad szpitalnictwem, prosił króla i Radę Nieustającą o wydanie odpowiednich przepisów wykonawczych (instrumentów) dla komisji dobrego porządku. Postulat ten zrealizowano w następnych reskryptach królewskich i rezolucji Rady Nieustającej z 17 grudnia 1782 r., w której nakazano Departamentowi Policji i komisjom dobrego porządku wspólpracę w zakresie funduszy szpitalnych ${ }^{51}$. W związku

${ }^{45}$ J. Bieniarzówna, J. M. M a lecki, Dzieje Krakowa. Kraków w wiekach XVI-XVIII, Kraków 1984, s. 569; M. Fra n čič, op. cit., s. 85.

${ }^{46}$ B.Ossol. nr 11866/III, s. 705-712; BUW nr 128, s. 8.

47 APK, nr 838, 839.

48 B.Czart., nr 897; B.Ossol., $\mathrm{nr} 65 / \mathrm{III}$.

49 Treść ustaw dla miasta J. K. Mci Poznania przez Kommissyq J.K. Mci Dobrego Porzqdku województwa poznańskiego w roku 1780 uchwalonych, Warszawa 1781.

so T. Srogosz, op., cit., s. 142-143.

51 AGAD, tzw. Metryka Litewska, dz. VII, nr 45, s. 85. 
z tym wzorcowa Komisja poznańska, która najintensywniej pracowała w latach 1779-1780, w ogóle nie podjęla tego problemu. Ze znanych $\mathrm{mi}$ materiałów źródłowych wynika, że najwcześniej rozpoznania funduszy szpitalnych dokonała Komisja ziemi wieluńskiej (do końca czerwca 1783 r.) ${ }^{52}$. Komisarze wieluńscy $w$ innych zagadnieniach wzorowali się na pracy swoich kolegów $\mathrm{z}$ województwa poznańskiego. Podporządkowanie się przepisom panującego prawa i decyzjom administracji centralnej nie przekreślało wlasnych inicjatyw elit. Przejawy samodzielności byly jednak sporadyczne i dotyczyły szczegółowych problemów. W swojej dzialalności komisarze trzymali się ram nakreślonych przez władze naczelne i wzorcowe ordynacje.

Poszczególne komisje dobrego porządku istniały do momentu wyboru komisarzy cywilno-wojskowych, czyli zakończyły działalność najpóźniej w 1790 r. Na podstawie zagadnień sanitarno-zdrowotnych można zaobserwować prawidlowość, która wyrażała się lepszą pracą komisji porządkowych cywilno-wojskowych $w$ tych ośrodkach, gdzie wcześniej sprawniej funkcjonowały komisje boni ordinis ${ }^{53}$. Polegało to na kontynuacji $w$ sferze koncepcyjnej i realizacyjnej. Część wladz lokalnych ustanowionych przez Sejm Czteroletni składała się z osób będących członkami komisji dobrego porządku (np. prezesem Komisji Porządkowej Cywilno-Wojskowej województwa lubelskiego zostal Kajetan Hryniewiecki ${ }^{54}$ ). Funkcjonowanie komisji dobrego porządku, opartych na tradycji samorządu szlacheckiego, miało duże znaczenie $w$ kształtowaniu lokalnych elit, mimo ograniczenia ich zadań do spraw miast królewskich. Działalność komisji stanowiła też ważny etap na drodze do tworzenia lokalnej administracji, z pełnym zakresem kompetencji.

52 AGAD, tzw. Metryka Litewska, dz. VII, nr 48, k. 92; APP, Akta miasta Grabów, $\mathrm{nr} \mathrm{I} / 18$, s. 5 .

53 T. S rogos z, op. cit., s. 300-306.

54 J. Ke rm is z, Lublin i Lubelskie w ostatnich latach Rzeczypospolitej (1788-1794), t. 1, $W$ czasie Sejmu Wielkiego $i$ wojny polsko-rosyjskiej 1792 r. oraz pod rzqdami targowicko-grodzieńskimi, Lublin 1939, s. 16. 